\title{
10
}

\section{ARABIC-BASED PIDGINS AND CREOLES}

\author{
Stefano Manfredi and Fida Bizri
}

\section{The definition of pidgin and creole languages: typological or sociolinguistic pertinence?}

The beginnings of the study of pidgin and creole languages as a distinct linguistic subdiscipline can be traced back to the second half of the 19th century, when Western scholars started to get interested in new languages that emerged in extreme contact situations induced by the European colonial expansion (Van Name 1869; Schuchardt 1882-1883). Despite this relatively long tradition, creolists still do not agree on what counts as a pidgin or a creole language. Generally speaking, pidgins and creoles represent new linguistic varieties resulting from asymmetrical contact between communities that do not share a common language. Each pidgin or creole is lexically related to the language that occupies the socially dominant position in the given contact situation and which is usually referred to as the 'lexifier' or the 'superstrate' language. The socially non-dominant languages, for their part, are said to represent the 'substrate' of pidgins and creoles. In contrast to the above generalizations, the dynamics of emergence of pidgins and creoles are still major issues of debate.

As far as pidgins are concerned, Holm (1988-1989: 4) states:

A pidgin is a reduced language that results from extended contact between groups of people with no language in common; it evolves when they need some means of verbal communication, perhaps for trade, but no group learns the native language of any other group for social reasons that may include lack of trust or of close contact.

In a similar way, Mühlhäusler (1997: 5) argues that:

pidgins are examples of partially targeted or non-targeted second language learning, developing from simpler to complex systems as communicative requirements become more demanding. Pidgin languages by definition have no native speakers, they are social rather than individual solutions and hence are characterized by norms of acceptability.

Thus, it is evident that pidgins differ from other spoken languages in one important sociolinguistic respect: namely, that they are nobody's first language. Furthermore, despite the fact 
that pidgins are said to have structural norms, they are generally thought to be less structurally elaborated than their lexifiers.

As regards creole languages, a traditional view is that they represent the nativized versions of pidgins. In this regard, Holm (1988-1989: 6) affirms that:

a creole has a jargon or a pidgin as its ancestry; it is spoken natively by an entire speech community, often one whose ancestors were displaced geographically so their ties with their original language and sociocultural identity were partially broken.

In this perspective, creoles are pidgins that have acquired native speakers, and have therefore expanded both their grammatical structures and functions. However, not all creolists think that creoles are preceded by a pidgin stage. For instance, Mufwene (2001) emphasizes that creoles and pidgins developed in dissimilar sociolinguistic. As a further matter, other scholars argue that the role of nativization is overestimated as a factor in explaining the structural differences between pidgins and creoles and that other social processes, such as urbanization, have a much stronger impact in terms of expansion and stabilization (). Against this backdrop, the issue of creole exceptionalism (i.e. the belief that

On the one hand, some creolists (Bakker et al. 2011; McWhorter 2001, 1998) overtly claim that creoles constitute a typologically definable group of languages with a unique set of structural features, mainly related to their lack of complexity due to them having resulted from a former process of pidgnization. On the other hand, it has been argued that the notion of 'creole' is exclusively sociolinguistic and that the emergence of a creole language is a historical development like any other process of language change (DeGraff 2004, 2005; Mufwene 2000, 2001). Either way, it is generally agreed that pidgin and creole languages are different from any other spoken language in that they came into existence at some point in time as a consequence of some form of disruption of the intergenerational transmission of a language from parent to child (Comrie 2011: 599). This means that before we can claim a language to be a pidgin or a creole, we need to know something about the sociohistorical conditions of its emergence. Consequently, only a multi-causal approach that combines both linguistic and sociolinguistic parameters can unveil the course of development of such languages.

In this chapter we are concerned with Arabic-based pidgins and creoles mainly from a sociolinguistic perspective. We briefly outline the main features of the Arabic-based pidgins or creoles. Next we describe the emergence as well as the contemporary sociolinguistic situation of the Arabic-based pidgins and creoles spoken in the Chado-Sudanese area and in the Middle East. In the final parts we give further sociolinguistic insight into the Arabic-based pidgins and creoles drawing on the analysis of language attitudes and the metalinguistic representations of these contact varieties vis-à-vis their respective lexifiers. The conclusions finally suggest further approaches which might be made to these marginal linguistic varieties.

\section{Arabic-based pidgins and creoles}

A number of Arabic-based contact languages have been claimed to be pidgins or creoles. ${ }^{1}$ Following Manfredi \& Tosco (2014: 207), we can classify these languages into two geographically, historically and structurally distinct groups: the Sudanic varieties which originated more than two centuries ago in Southern Sudan within the context of the slave trade, and the Asian Migrant Arabic Pidgins (as defined by Bizri 2014b) spoken today throughout the Middle East. 


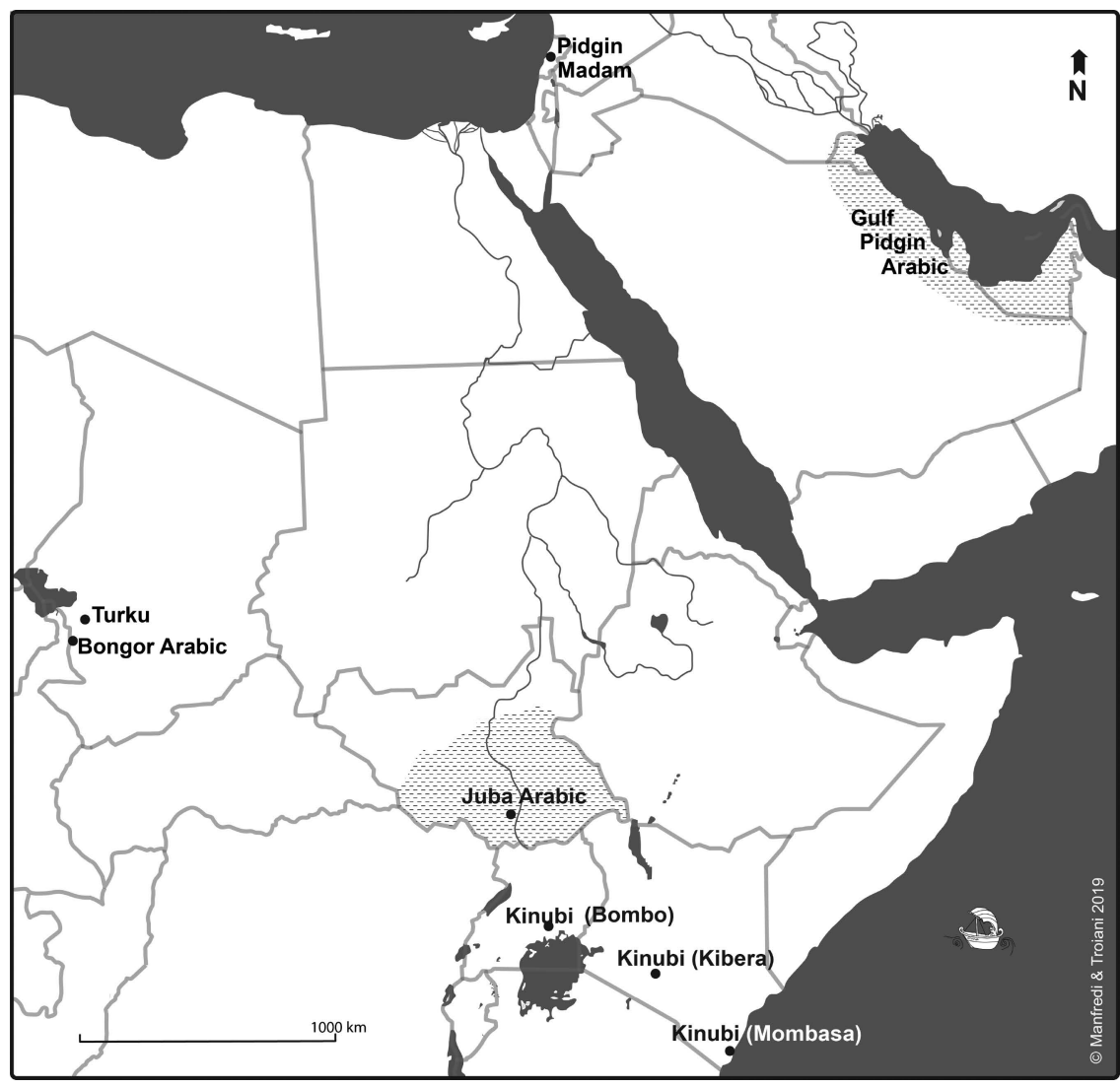

On structural grounds, Arabic-based pidgins and creoles are characterized by a drastic restructuring of their lexifiers. This is mainly because second language acquisition with a limited linguistic input entails different processes such as substratum interference, simplification $^{2}$ as well as language internal developments. Tosco \& Manfredi (2013: 499) offer a list of phonological and morphosyntactic features that can be safely said to represent most Arabic-based pidgins and creoles. The main points can be summarized as follows:

- pharyngealization is universally lost;

- the velar fricatives merge with their plosive counterparts;

- consonant gemination and vowel length are universally lost;

- the Arabic root-and-pattern morphology is no longer productive;

- $\quad$ loss of the definite article $a l$-;

- loss of gender as a morphological category;

- presence of a single independent set of personal pronouns;

- the analytic expression of possessive relations is generalized.

Despite the above sketched features, the linguistic profile of each variety varies a great deal according to the different sociolinguistic contexts in which these varieties arose. 


\section{Sudanic Arabic-based pidgins and creoles}

Sudanic pidgins and creoles constitute a coherent group of Arabic-based contact varieties whose origins can be traced back to the expansion of the Egyptian colonial rule in southern Sudan in the 19th century. Most plausibly, Sudanic pidgins and creoles originated as a consequence of an asymmetric contact situation between enslaved Nilotic populations and a dominant minority of Arabic-speaking traders coming from northern Sudan and Egypt. It has been suggested that a pidginized variety of Arabic was already in use before the beginnings of the slave trade in Sudan (Owens 1985, 1996). Despite this, it is now generally acknowledged that the emergence of Sudanic Arabic-based pidgins and creoles is a direct consequence of the slavery system imposed by the advent of Muhammad Ali's expeditions in southern Sudan in 1821 (Tosco \& Manfredi 2013). As a matter of fact, the gradual establishment of slave camps in the southernmost part of Sudan changed the local social relationships to such an extent that a pidginized form of Arabic arose as an interethnic means of communication between Arab slave riders and local groups. ${ }^{3}$ This pidgin, which is generally labeled Early East African Pidgin Arabic (Kaye \& Tosco 1993), is said to represent the common linguistic ancestor of three distinct linguistic varieties. These are the Ki-Nubi creole spoken in Uganda and Kenya (Owens 1977; Heine 1982; Luffin 2005; Wellens 2005), the Juba Arabic pidgincreole spoken in the nowadays South Sudan (Mahmud 1979, 1983; Manfredi 2017), and the Turku pidgin once spoken in western Chad (Tosco \& Owens 1993). ${ }^{4}$ In this section we are concerned only with Juba Arabic and Ki-Nubi which represent the best documented varieties of Sudanic pidgins and creoles so far.

Starting with Juba Arabic, it has been traditionally considered a pidgin (i.e. a non-native language) by creolists. However, a better label would be that of pidgincreole. This is an intermediary category between pidgins and creoles which is defined by the fact that an earlier pidgin became the first language only for part of its speakers (Bakker 2008). As a matter of fact, Juba Arabic is spoken either as a first or second/third language in South Sudan. More to the point, the quantitative analysis of sociolinguistic data done by Manfredi \& Tosco (2018) reveals that at the present time Juba Arabic represents the native language (here intended as a chronologically first language) for almost a half (47\%) of the urban population of Juba. At the same time, it is still widely used as an interethnic means of communication between local groups having different ethnolinguistic backgrounds. Being spoken side by side with different Nilotic languages (these are mainly Bari dialects), the present day adstrate of Juba Arabic most nearly corresponds to the original substrate of Early East African Pidgin Arabic. In this overall situation, Juba Arabic has gradually integrated both lexical and grammatical items from local languages (Miller 1984; Nakao 2012). This mainly concerns the slang used by the youngest urban population of Juba (Miller 2004; Nakao 2013). As a further matter, Juba Arabic has a relatively long written tradition both in Arabic and Latin scripts (Miller 2014). Despite this, mainly as a consequence of the ideological reaction to the process of Arabicization enacted by the former unified Sudan, Juba Arabic is recognized as neither an official nor national language of the current Republic of South Sudan (Manfredi \& Tosco 2018). That being so, unlike other local languages, Juba Arabic is not taught in primary schools.

As far as Ki-Nubi is concerned, it originated as a consequence of forced population displacement from southern Sudan following the eruption of the Mahdist revolt in 1884 (Owens 1985, 1990). It currently represents the first language of nearly 25,000 speakers (Wellens 2007: 588) scattered throughout Uganda and Kenya. In light of the above, Ki-Nubi can well be considered a fully nativized creole. Owens (1977) and Heine (1982) describe the Kenyan 
variety of Nairobi, while Luffin (2005) furnishes a description of the Ki-Nubi variety of Mombasa. Wellens (2005), on her part, published the only detailed study of the Ugandan Ki-Nubi of Bombo so far. Despite the presence of a number of diatopic variants (e.g. the plural suffixes $-a ́ t,-a ́)$, the lack of major grammatical differences between the different varieties of Ki-Nubi is evidence of an early process of creolization. On social grounds, unlike Juba Arabic which is widely spoken by both Muslim and Christian South Sudanese groups, Ki-Nubi represents the primary language of Muslim communities. Furthermore, being spoken as a minority language in a Swahili-dominant environment, Ki-Nubi became an important marker of ethnic identity for its speakers (Tosco \& Manfredi 2013: 503). It has been argued that Ki-Nubi is basically an oral language with little or no written documentation (Wellens 2005: 9). However, following the advent of the internet, we are witnessing a rapid emergence of blogs and sites in informal written Ki-Nubi.

From a structural point of view, Juba Arabic and Ki-Nubi display a common core of features (Manfredi \& Petrollino 2013; Luffin 2013) that can only be explained by the fact that early East African Pidgin Arabic had already reached a stable stage of development. The differences between Juba Arabic and Ki-Nubi are mainly related to the higher degree of functional expansion of the latter as well as to the strong adstrate influence played by Swahili on the Eastern African creole (Luffin 2014). Furthermore, as it is spoken in South Sudan, Juba Arabic is likely to be affected by the influence of Sudanese Arabic (Versteegh 1993). Despite this, Juba Arabic speakers are generally aware of the distinctiveness of their language and tend to keep it apart from its lexifier (see below).

\section{Middle Eastern Arabic-based Pidgins}

A number of pidginized forms of Arabic emerged in the Middle East following the oil-boom of the 1970s and the subsequent immigration of foreign workers to the Gulf area and neighbouring countries. One of these varieties, referred to as Romanian Pidgin Arabic (Avram 2010), was formerly spoken in Iraq between Romanian migrant workers and local Iraqi employers in oil companies. Today, several other pidginized varieties are still spoken throughout the Middle East by Arab employers and Asian migrants who occupy subordinate job positions often considered the lowest in the employment hierarchy of their host countries (housemaids, cleaners, janitors, sales clerks, construction workers, etc.). In spite of individual characteristics that distinguish one variety from the other, they all emerged from the same social setting, and they all exhibit similar linguistic strategies and forms.

Of all the African and Asian migrants that work in the Middle East, only those from the Indian subcontinent (Pakistan, India, Nepal, Bangladesh and Sri Lanka) and, to a lesser extent, South East Asian migrants (from the Philippines, Indonesia and Malaysia) have developed some form of pidginized Arabic. This supports the hypothesis of a South Asian cluster of substrate languages where Hindi/Urdu, Tamil, Malayalam, Punjabi, Pashto, Bengali, Nepali and Sinhala are largely overrepresented, along with Tagalog, Javanese and Chavacano from South East Asia. Hence the linguistic label ' Asian Migrant Arabic Pidgins,' (hereafter AMAP) proposed by Bizri (2014b). It should be noted that, although the term 'substrate' usually designates indigenous languages that came into contact with an outsider language, it is used here to designate migrants' first languages. Different from what is observed in traditional pidgins whose lexifier language migrates to new territories where it is a demographically minor language in spite of its dominant position, in the case of the Middle Eastern Arabic-based pidgins the superstrate is 'at home' while the substrate is represented by outsider languages. 
The study of AMAP is based on data collected from publications on several varieties attested throughout the Middle East: a variety called Gulf Pidgin Arabic attested in the UAE and neighbouring countries (Smart 1990). ${ }^{5}$ Al-Azraqi (2010) and Al-Moaily (2008, 2013, 2014) present data collected in Saudi Arabia, to which the cited authors refer with the respective tags Asian Arabic Pidgin and Urdu Pidgin Arabic; Al-Salman 2013, Al-Haq \& Al-Salman 2014 present data from Jordanian Bengali Pidgin; the pidgin attested in Lebanon and called Pidgin Madam (Bizri 2004, 2005, 2009, 2010, 2013), differs from the previous varieties in that it is spoken exclusively by Sinhala-speaking Sri Lankan female maids and their female Arabic-speaking employers. In fact, if we were to ignore the attested mobility of the same Sinhala-speaking housemaids across the Arab world, then Pidgin Madam would appear to be an exception to the norm, since in this case speakers produce a pidginized variety with only one substrate language involved. Pidgin Madam (PM) can, therefore, be counted as one of a series of counterexamples, like Trio-Ndyuka Pidgin (Huttar \& Velantie 1997), to the argument that pidgins can only develop in an environment where speakers of at least three languages are compelled to communicate (Whinnom 1971).

The cheap-labour Asian migration to the Middle East is a 'circular' one (as defined in Zapata-Barrero et al. 2012), which means that the mobility of the labour migrants is (potentially) permanent but always with a temporary status, since their migration involves a periodic return home. Many of the informants who provided the data published in the various studies focusing on AMAP varieties either had been to another country before working in the one where they were recorded, or were considering travelling to another Arab country in the future. It seems the differences between distinct varieties of AMAP are not due to differences amongst the national koinés of the various Arab countries ${ }^{6}$ but rather to other (non-geographic/nondialectal) sociolinguistic factors.

The development of the varieties in question is highly context-sensitive and contextdependent. Rather than a geographical or ethnic distinction, what distinguishes one pidginized variety from the other is of paralinguistic nature: the gender parameter for instance, or the confinement parameter determining the scope of exposure to the Arabic continuum. Therefore, one can distinguish between two main sub-groups within AMAP: live-in migrant speech and free-lance migrant speech. The live-in female housemaid situation is defined by its feminine bias (female housemaids interacting mainly with female employers, housewives), its confined space (maids are rarely allowed to go out), its reduced exposure to Arabic (except when access to local TV is allowed) and limited interactions with Arabs and/or other foreign migrants outside the circle permitted by the employers. Free-lance migrants are exposed to a richer palette with no specific gender bias and are expected to respond more actively to a wider spectrum of interactions with both Arabs and non-Arabs. This distinction which has been underlined in sociolinguistic studies of the Asian migration phenomenon (Jureidini \& Moukarbel 2004; Jureidini 2009; Moukarbel 2009), has many linguistic implications, one of which is the status of the grammatical feminine gender feature in live-in housemaids' speech.

All AMAP varieties have been described as pidgins or pre-pidgins because of their incipient and still unstable nature. Their classification is in fact difficult because of the high degree of inter- and intra-personal variation they exhibit. Despite this, following Mühlhäusler's distinction (1997: 5) they can be classified as pre-pidgins or jargons (as opposed to stable pidgins and pidgincreoles). According to another classification proposed by Winford (2006) they can also be classified as Stage 1 pidgins considering that their structural characteristics are similar to those present in the stages of interlanguage typical of second language acquisition processes. Stage 1 pidgins, like Mühlhäusler's pidgins, are characterized by a minimal syntactic structure and a quasi-complete absence of functional categories. 
Due to their early stage of development, their contemporary existence, and the high degree of variability they show, the AMAP pidginized varieties represent a highly valuable laboratory where mechanisms of linguistic change can be observed ab ovo. The development of migrant speech and of domestic servants' speech varieties is fairly well attested in other parts of the world. Gastarbeiter Deutsch in Germany (inter alia Blackshire Belay 1991; Klein \& Dittmar 1979 ) is one example of a migrant speech variety that developed in a similar context. Likewise, Butler English spoken in India with Indian domestic workers and their British employers during the colonial administration (Hosali 2000) is another example of a pidginized variety of a target language spoken by domestic servants in interaction with their masters.

\section{Language attitudes and metalinguistic awareness}

The notion of language attitudes generally refers to reactions, beliefs and values that people have about their language and the languages of others (Copper \& Fishman 1974). Metalinguistic awareness, on its part, defines the individual ability/inability to assess the structural features of a given language and to use them with appropriate social meaning. Both language attitudes and metalinguistic awareness rely on ideological representations of language that are affected by cognitive and social factors. In this section we propose an analysis of some instances of language attitudes and metalinguistic awareness related to Juba Arabic and AMAP varieties. This is basically intended to introduce metalinguistic discourse as an effective means of investigation of Arabic-based contact varieties. Data about the South Sudanese pidgincreole are drawn upon formal interviews recorded in Juba as well as upon spontaneous conversations of South Sudanese displaced people living in Khartoum. Data about AMAP are mainly representative of written discourse on these contact varieties.

Concerning Juba Arabic, Miller (2000) has remarked that this Arabic-based pidgincreole started to be used as a marker of a super-tribal South Sudanese identity after the signing of the Addis Abeba peace agreement in 1972. Despite the fact that Juba Arabic has no official status in South Sudan, the link between national identity and the Arabic pidgincreole has been further strengthened during the second Sudanese civil war (1983-2005) and after the independence of South Sudan in 2011. In this ideological context, it is important to remember that Juba Arabic is spoken alongside different varieties of Arabic. First of all, Sudanese Arabic, the former socially dominant language of Sudan, is still widely spoken in South Sudan by people of northern Sudanese descent and many South Sudanese who had spent the civil war period in Khartoum. The prolonged contact with the lexifier language gave rise to a continuum of speech forms ranging from the creole (i.e. basilect), through intermediary forms (i.e. mesolect), to Sudanese Arabic (i.e. acrolect). In spite of this situation, speakers seem to have a very clear metalinguistic awareness of the distinctiveness of their language as we can see in the following excerpt from an interview recorded in Juba in 2013.

úo má arabi/hási fi șamál/fi kartúm/músu ûmon kélim gal luġa 'arabiyya // úmon bi-nadí gal lugia // le ánna zátu/árabi júba kamán bi-nadi gal lugia // [ . . ] zey ána bi-kélim gal/ána bi-kélim le ita // lakín úmon henák/úmon bi-kélim gal/b-a-gūl l-ēk // It (i.e. Juba Arabic) is not Arabic. Now in the north, in Khartoum, don't they call it 'the Arabic language'? They call it 'language'. So have we, Juba Arabic is called 'language'. [. . .] For example, I usually say: ána bi-kélim le ita ('I say to you'), but over there they say: $b$-a-gūl l l-êk ('I say to you').

(Manfredi and Tosco fieldwork data) 
The relevance of this excerpt does not lie just in the affirmation that Juba Arabic is a 'language' $(\operatorname{lug} a)^{7}$ on its own and that it is distinct from Sudanic Arabic ${ }^{8}$ but rather in the fact that the speaker provides a linguistic discriminant for distinguishing the pidgincreole from its lexifier. That is neither its lexicon (which is obviously of Arabic origin) nor its reduced phonology (which is not peculiar to Juba Arabic in the Sudanese area). According to the speaker, the distinctiveness of Juba Arabic rather resides in its isolating morphology (exemplified by the opposition between the analytic phrase ána kélim le ita [lit. 'I speak to you'] and the synthetic $b$-a-gül l-êk [lit. 'I-am-saying to-you']) which is likely to be cognitively more prominent than other linguistic features. This representation is of particular analytical interest given that one of the most commonly alleged features of pidgin and creole languages is represented by the isolating nature of their morphosyntactic structures (see above).

As a further matter, it should be stressed that Juba Arabic is in contact with non-native varieties of Arabic which are generally referred to as árabi al besit 'simple Arabic.' These varieties of Arabic are basically used as an interethnic medium of communication on the borders between Sudan and South Sudan and they are said to be less restructured grammatically than Juba Arabic mainly because they largely preserved the Arabic agglutinative morphology (Manfredi 2013a). It seems that some kind of difference between Juba Arabic and non-native varieties of Arabic is acknowledged also by the speakers of the South Sudanese pidgincreole as we can see in the following excerpt of spontaneous conversation recorded in Khartoum in 2009 .

ita áynu/nas wáu/árabi tómon/geríb zey árabi júba // lakín úmon g-ámulu hája tómon baráu // [ . . ] u úmon der jíbu geríb ma árabi juba // wa geríb ma árabi ta jama-át del // bes ya kéda // ăsán kéda úmon má b-ágder senú/bi-límu sáwa //

You see? The people of Wau, their Arabic, is somewhat similar to Juba Arabic. But they do something different. [...] They want to make (it) similar to both Juba Arabic and the Arabic spoken by those people (i.e. the northern Sudanese). It is just like this. For this reason, what they (i.e. the people of Wau) cannot do is to gather together.

(Manfredi 2013b)

In the previous excerpt the speaker makes reference to the non-native variety of Arabic spoken in Wau, the administrative capital of the Bahr al-Ghazal region lying in the north-west of South Sudan. According to him, Wau Arabic cannot be considered to be a variety of Juba Arabic because of its resemblance to Sudanese Arabic. More interestingly, the speaker overtly states that the absence of a linguistic distinctiveness hinders the affirmation of a common identity for the speakers of Wau Arabic who are said not to be able 'to gather together' as in the case of Juba Arabic speakers. Above and beyond, this shows how the analysis of speakers' metalinguistic awareness could be used in combination with linguistic description in order to assess the sociolinguistic and linguistic status of different contact varieties.

Moving on to AMAP varieties, they are derogatorily referred to by Arabophones with generic labels such as Sarabi mkassar 'broken Arabic' or, in the Gulf area, kaläm hnüd 'Indian Talk' ('Indian' being the generic designation prevalent in the Gulf area for all migrants from South Asia irrespective of their actual nationality); or, in the case of Lebanon, hake sennēs 'maids' talk' and, more frequently, Sarabe serlankiyyēt 'Arabic of Sri Lankans-FEM' ('Sri Lankan' being the Lebanese generic designation of 'maid from South Asia,' probably due to the Sri Lankan pioneer arrival to Lebanon during the war-torn years of the 1980s and to 
their numeric prominence up until 2004-2006 when they gradually began to be replaced by Ethiopians).

The existence of a pidginized variety of Arabic used to communicate with the migrants turns out to be an excellent linguistic barrier spontaneously encouraged by Arabs to protect their privacy from the migrants who are often regarded as 'intimate outsiders' (Bizri 2014a) to keep them in a hierarchically inferior position. This is especially true in the case of housemaids where migrants are considered to be intruders although their very presence may stem from the employers' wish.

Pidginized Arabic is also perceived by most Arabs as being 'comical' (Bizri 2010; selection of web pages in the final bibliography). Arabs, therefore, willingly include in their humoristic repertoire the pidginized variety they interact with (or rather their own representation thereof, for their perception of migrant speech differs from the actual migrant speech, although both may correspond and overlap in many respects). Many songs, satirical poems and teledrama script lines are composed in this medium as shown in the following two figures. Writing AMAP varieties has so far been documented only in the Gulf area (not in the Levant). Both Roman and Arabic scripts are used. The former seems to be limited to migrant exchange in online spaces, while the latter seems to be largely adopted by Arabs themselves as a satirical, somehow subversive, and definitely comical way to compose humorous texts.

Example 1: Surat an-nās from the Quran as it is said to have been translated by an 'Indian' but is most likely to be a composition of a native-Arabic speaker. ${ }^{9}$ Source: http://sudaneseon line.com

$$
\begin{aligned}
& \text { شيطان يجي قلب سوي قرقر كتير } \\
& \text { انت سمع انت خسارة } \\
& \text { انت مافي سمع انت يو قيامة في فايدة }
\end{aligned}
$$

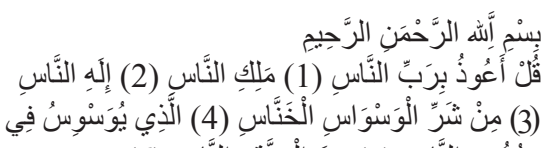

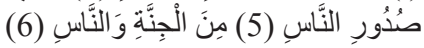

Translation:

In the name of God, the entirely merciful, the especially merciful. Say, "I seek refuge in the Lord of mankind, The Sovereign of mankind. The God of mankind, From the evil of the retreating whisperer - Who whispers [evil] into the breasts of mankind - From among the jinn and mankind."

Example 2. Arabic proverbs (on the left below) and their pidgin equivalents (on the right) presented online as "Indian proverbs with their Arabic translation." Source: http://arab-jokes.net/

$$
\text { الباب اللي بجيك منو ريح سدو واستريح }
$$

سكر باب مزبوط بعدين مايجي هوا

Translation: Close the door when it gets windy, i.e. avoid the source of certain problems

$$
\text { خير الكلام ماقل ودل }
$$$$
\text { مايسوي زيادة قرقر . ... . صغير كلام مزبوت }
$$

Translation: The best speech is concise and clear

$$
\text { يخلق من الثبه أربعين }
$$

سيم سيم • ع نفر

Translation: (God) creates 40 people all the same shape (said whenever someone is mistaken for someone else)

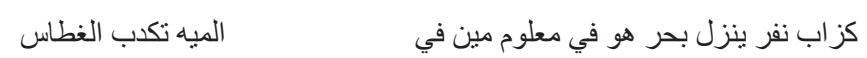

Translation: water belies the diver, i.e. it's only by swimming that we prove our swimming skills, not by bragging about them 


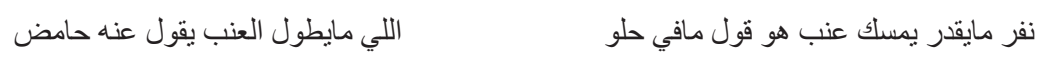

Translation: Whoever is unable to reach the grapes, pretends they are sour

$$
\text { انا اخو في سوا سوا يضرب راجو، انا راجو في سو اسوا اناو واخوي على ابن عمي واناو ابن عمي عالغريب }
$$

Translation: I stand with my brother against my cousin, and with my cousin against strangers. i.e. one keeps changing alliances

In spite of the derogatory labels attached by Arabs to these varieties, and in spite of the obstacles that migrants encounter while trying to understand other forms of Arabic they are passively exposed to (either through TV or by witnessing inter-Arab communication), migrants consider the new language they speak to be Arabic. When asked to assess (in their mother tongue) the different varieties of Arabic that surround them, the Sinhala housemaids in Lebanon argued that, in their understanding, all linguistic traits of the Arabic language that are not related to PM were to be labeled 'formal Arabic,' that is, 'another language.' They often give Sinhala diglossia as an example, pointing out that Sinhala has virtually two totally different languages. Learning colloquial Sinhala does not enable one to understand formal Sinhala. By perceiving the diglossia inherent to Arabic, and by recognizing Lebanese Arabic as a different norm, Sinhala maids accept their own exclusion from it. However, by doing so, they subsume under 'formal Arabic' a whole range of linguistic traits which do not belong to that label, being associated rather with standard Lebanese Arabic (Bizri 2014a).

Moreover, for migrants, Arabic turns out to be an extraordinarily valuable economic tool which enables them to travel across the Middle East. Arabic, being a transnational language, is equivalent to gold, or rather (for the more experienced migrants), Arabic (owing to a wide job market) is at least a promise of gold. The knowledge of Arabic (as pidginized as it may be), therefore, represents for the migrants navigating across the cheap-labour marketplace a symbolic capital in Bourdieu's sense (1991). As one Sri Lankan maid puts it, trying to convince her sister to go to Kuwait instead of Israel (following the proposition of some Sri Lankan agents who were offering Israel as a destination with the promise of 25 dollars a month more than in any Arab country): "If you go to Israel, you're finished! Arabs won't take you anymore. And what if it goes wrong in Israel? You will have nowhere else to go. Whereas by going to Kuwait, suppose you're fed up of Kuwait, you can go to another country, because you speak Arabic" (Bizri, excerpt of a series of interviews conducted in Sri Lanka in 2000). Another maid explains: 'My husband drank [the money of] nine years of my life in Kuwait and Lebanon. But I don't care now that he's left, because I know Arabic. I know this will always push me forward' (Bizri 2014a).

Knowledge of Arabic appears, therefore, to be a stepping stone towards a better life. Not only the Arabic language itself, but the whole aura that comes with it may be perceived as assets for gaining a better social position back home. This is particularly true for Muslim migrants who regard Arabic as the sacred language of the Quran. For instance, for Sri Lankan Muslim female domestic migrants in Saudi Arabia and the Gulf area, the Arabic language and the Islamic culture it conveys seem to be valuable assets that they can use to successfully renegotiate their status in their Muslim villages back home (Thangarajah 2003).

In sum, the representation of AMAP ranges from a medium willingly or unwillingly used by Arabic speakers to maintain the migrants in a contained subordinate status, to an emblematic tool of success used by migrants to enhance their mobility across the Arab world ensuring thus the promise of a continuous flow of money, as little as it may be. 


\section{Conclusion}

The study of Arabic-based pidgins and creoles appears to be relevant to sociolinguistics in general and to Arabic sociolinguistics in particular for enriching the debate with data from marginal varieties of Arabic (also see Grigore, this volume). It also yields many insights for theories concerning the emergence of pidgins and creoles which were, until recently, exclusively based on pidgins and creoles whose lexifiers were European languages such as English, French, Dutch and Portuguese. Furthermore, Arabic-based pidgins and creoles that are still spoken today represent a valuable observatory for the dynamics of language change as well as for the analysis of its metalinguistic representations. Despite this, valuable variationist studies are still lacking, especially in the case of Sudanic Arabic-based contact varieties.

\section{Notes}

1 The debate on whether modern Arabic dialects emerged from a process of pidginization and a following creolization and de-creolization (Versteegh 1984, 2004, see Manfredi forthcoming) is largely disregarded in this chapter.

2 Simplification is here understood in relation to the Arabic lexifier. In this regard, it should be stressed that some creolists argue that no process of simplification goes on in creolization and that the notion of simplicity is irrelevant to understanding creole structures and genesis (Aboh 2009).

3 On the basis of colonial documentation, Owens $(1990 ; 1996)$ estimated that in the second half of the 19th century, a fifth of the entire south Sudanese population (nearly 60,000 individuals) was resident in the slave camps or in other trading settlements and only a quarter thereof was composed of Arabophone groups mainly from northern Sudan and Egypt.

4 Bongor Arabic (Luffin 2007) is a Turku-like variety nowadays spoken in the Mayo-Kebbi region in western Chad. However, according to Tosco and Manfredi (2013: 503), this variety went through a process of depidginization due to the influential role played by Chadian Arabic.

5 Also see, for Kuwait (Wiswall 2002; Dashti 2013); for Oman (Naess 2008); and for Qatar (Bakir 2010).

6 We note that when Asian migrants exhibit dialectal variation in their Arabic, this is always restricted to with lexical items.

7 The occurrence of the velar realization [ $\dot{\mathrm{g}}]$ in the lexeme lug $a$ 'language,' together with the pharyngeal realization [C] and the glide gemination in 'arabiyya 'Arabic' can be taken as a proof of an instance of codeswitching toward Sudanese Arabic used for highlighting reported speech.

8 The label 'Sudanic' makes reference to the macro-dialect encompassing the entire Arabic-speaking region going from northern Nigeria, in the west, to the Red Sea, in the east, and which includes Sudanese Arabic, the urban koine of Sudan. Being lexified by different Sudanic dialects, Arabic-based pidgins and creoles spoken in the region are also referred to as Sudanic Pidgins and Creoles (Tosco \& Manfredi 2013).

9 In the text below, the version on the right is that if the original Quranic verse, and on the left is a pidginized translation of the verse, which would be incomprehensible to an Arab.

\section{References}

Aboh, Enoch O. 2009. Competition and selection: That's all! In Enoch O. Aboh \& Norval Smith (eds.), Complex processes in new languages, 317-344. Amsterdam: Benjamins.

Al-Azraqi, Munira. 2010. Pidginization in the Eastern region of Saudi Arabia: Media presentation. In Reem Bassiouney (ed.), Arabic and the media. Linguistic analyses and applications, 159-174. Leiden: Brill.

Al-Haq, Fawaz \& Abdul Karim Al-Salman. 2014. Jordanian Bengali Pidgin Arabic. US-China Foreign Language 2(5). 331-348.

Al-Moaily, Mohammad. 2008. A data-based description of Urdu Pidgin Arabic. MA thesis, University of Newcastle upon Tyne.

Al-Moaily, Mohamad. 2013. Language variation in Gulf Pidgin Arabic. Ph.D. thesis, University of Newcastle upon Tyne. 
Al-Moaily, Mohammad. 2014. Language variation in Gulf Pidgin Arabic. In Irene Buchstaller, Anders Holmberg \& Mohammad Almoaily (eds.), Pidgins and creoles beyond Africa-Europe encounters, 57-83. Amsterdam: John Benjamins.

Al-Salman, Abdul Karim. 2013. Jordanian Pidgin Arabic. MA thesis, Yarmuk University.

Avram, Andrei. 2010. An outline of Romanian Pidgin Arabic. Journal of Language Contact 3. 20 -38.

Bakir, Murtadha J. 2010. Notes on the verbal system of Gulf Pidgin Arabic. Journal of Pidgin and Creole Languages 25(2). 201-228.

Bakker, Peter. 2008. Pidgins versus creoles and pidgincreoles. In Silvia Kouwenberg \& John Victor Singler (eds.), The handbook of pidgin and creole studies, 130-157. Oxford: Blackwell.

Bakker, Peter, Aymeric Daval-Markussen, Mikael Parkvall \& Ingo Plag. 2011. Creoles are typologically distinct from non-creoles. Journal of Pidgin and Creole Languages (1). 5-42.

Bizri, Fida. 2004. Le Pidgin Arabe des Domestiques Singhalaises au Liban. Ph.D. thesis, Ecole Pratique des Hautes Etudes: Paris.

Bizri, Fida. 2005. Le Pidgin Madame: Un nouveau pidgin arabe. La Linguistique 41(2). 54-66.

Bizri, Fida. 2009. Sinhala in contact with Arabic: The birth of a new pidgin in the Middle East. In Rajendra Singh (ed.), Annual review of south Asian languages and linguistics, 135-148. Berlin: Mouton de Gruyter.

Bizri, Fida. 2010. Pidgin Madame: Une grammaire de la servitude. Paris: Geuthner.

Bizri, Fida. 2013. Pidgin Madam. Brill, online encyclopedia of Arabic language and linguistics. http:// referenceworks.brillonline.com/browse/encyclopedia-of-arabic-language-and-linguistics.

Bizri, Fida. 2014a. Maids' talk: Linguistic containment and mobility of Sri Lankan housemaids in Lebanon. In Victoria Haskins \& Claire Lowrie (eds.), Colonization and domestic service: Historical and contemporary perspectives, 164-192. Routledge International Studies of Women and Place. Oxford: Routledge.

Bizri, Fida. 2014b. Unity and diversity across Asian migrant Arabic pidgins in the Middle East. In Stefano Manfredi \& Mauro Tosco (eds.), Arabic-based pidgins and creoles, special issue of Journal of Pidgin and Creole Languages 29(2). 391-415.

Blackshire Belay, Carol. 1991. Language contact: Verb morphology of foreign workers. Tübingen: G. Narr.

Bourdieu, Pierre. 1991. Language and symbolic power. Cambridge: Harvard University Press.

Comrie, Bernard. 2011. Creoles and language typology. In Claire Lefebvre (ed.), Creoles, their substrates, and language typology, 599-611. Amsterdam: John Benjamins.

Cooper, Robert L. \& Joshua A. Fishman. 1974. The study of language attitudes. Linguistics 12(136). $5-20$.

Dashti, Abdulmohsen A. 2013. Interacting with domestic workers in Kuwait: Grammatical features of foreigner talk. A case study. International Journal of the Sociology of Language 224. 63-84.

DeGraff, Michel. 2004. Against creole exceptionalism. Language 79(2). 391-410.

DeGraff, Michel. 2005. Linguists' most dangerous myth: The fallacy of creole exceptionalism. Language and Society 34. 533-591.

Heine, Bernd. 1982. The Nubi language of Kibera - an Arabic creole. Berlin: Reimer.

Holm, John. 1988-1989. Pidgins and creoles, 2 volumes. Cambridge: Cambridge University Press.

Hosali, Priya. 2000. Butler English: Form and function. Delhi: B. R. Publishing Corporation.

Huttar, George \& Frank Velantie. 1997. Ndyuka-Trio Pidgin. In Sarah G. Thomason (ed.), Contact languages. A wider perspective, 99-124. Amsterdam: John Benjamins.

Jureidini, Ray. 2009. In the whadows of family life: Towards a history of domestic service in Lebanon. Journal of Middle East Women's Studies 5(3). 74-101.

Jureidini, Ray \& Nayla Moukarbel. 2004. Female Sri Lankan domestic labour in Lebanon: Contractual, slavery-like practices and conditions. Journal of Ethnic and Migration Studies 30(4). 581-607.

Kaye, Alan S. \& Mauro Tosco. 1993. Early east African Pidgin Arabic. Sprache und Geschichte in Afrika 14. 269-305.

Klein, Wolfgang \& Norbert Dittmar. 1979. Developing grammars. The acquisition of German syntax by foreign workers. Berlin: Springer.

Luffin, Xavier. 2005. Un créole arabe: le Kinubi de Mombasa, Kenya. München: Lincom.

Luffin, Xavier. 2007. Bongor Arabic. In Kees Versteegh et al. (eds.), Encyclopedia of Arabic language and linguistics, 634-639, Volume 1. Leiden: Brill.

Luffin, Xavier. 2013. Kinubi. In Susanne M. Michaelis, Philippe Maurer, Magnus Huber \& Martin Haspelmath (eds.), The survey of pidgin and creole languages volume III. Contact languages based on languages from Africa, Australia, and the Americas, 50-53. Oxford: Oxford University Press. 
Luffin, Xavier. 2014. The Swahili influence of Ki-Nubi. In Stefano Manfredi \& Mauro Tosco (eds.), Arabic-based pidgins and creoles, special issue of Journal of Pidgin and Creole Languages 29(2). 299-318.

Mahmud, Ushari. 1979. Variation in the aspectual system of Juba Arabic. Ph.D. thesis, Georgetown University.

Mahmud, Ushari. 1983. Arabic in the southern Sudan: History and spread of a pidgincreole. Khartoum: Khartoum University Press.

Manfredi, Stefano. 2013a. Native and non-native varieties of Arabic in an emerging urban centre of Western Sudan. In Mena Lafkioui (ed.), African Arabic: Approaches to dialectology, 13-51. Berlin: Mouton de Gruyter.

Manfredi, Stefano. 2013b. Juba Arabic corpus. In Amina Mettouchi, Martine Vanhove \& Dominique Caubet (eds.), CorpAfroAs - A corpus for Afro-Asiatic languages, http://corpafroas.huma-num.fr/ Archives/corpus.php.

Manfredi, Stefano. 2017. Arabi Juba: un pidgin-créole du Soudan du Sud. Lauvain-la-Neuve: Peeters.

Manfredi, Stefano. Forthcoming. The Arab World. In Umberto Ansaldo \& Miriam Meyerhoff (eds.), The Routledge handbook of pidgin and creole languages. London: Routledge.

Manfredi, Stefano \& Sara Petrollino. 2013. Juba Arabic. In Susanne M. Michaelis, Philippe Maurer, Magnus Huber \& Martin Haspelmath (eds.), The survey of pidgin and creole languages volume III. Contact languages based on languages from Africa, Australia, and the Americas, 54-65. Oxford: Oxford University Press.

Manfredi, Stefano \& Mauro Tosco. 2014. Introduction. In Stefano Manfredi \& Mauro Tosco (eds.), Arabic-based pidgins and creoles, special issue of Journal of Pidgin and Creole Languages 29(2). 207-210.

Manfredi, Stefano \& Mauro Tosco. 2018. Juba Arabic (Arabi Juba): a "less indigenous" language of South Sudan. Sociolinguistic Studies 12(2). 209-230.

McWhorter, John H. 1998. Identifying the creole prototype: vindicating a typological class. Language 74(4). 788-818.

McWhorter, John H. 2001. The world's simplest grammars are creole grammars. Linguistic Typology 5. 125-166.

Miller, Catherine. 1984. Bari interference in Juba Arabic. In Lionel Bender (ed.), Proceedings of the 4th Nilo-Saharan symposium, 1-10. Tubingen: Helmut Buske.

Miller, Catherine. 2000. Juba Arabic as a way of expressing a southern Sudanese identity in Khartoum. In Abdelrahim Youssi, Fouzia Benjelloun \& Mohamed Dahbi (eds.), Contemporary Arabic dialects. Proceedings of the 4th Aida meeting, 114-122. Rabat: Amapatril.

Miller, Catherine. 2004. Un parler argotique à Juba. In Jacqueline Billiez, Thierry Bulot, Dominque Caubet, Isabelle Léglise \& Catherine Miller (eds.), Les Parlers Jeunes. Ici et là-bas, 69-90. Paris: Harmattan.

Miller, Catherine. 2014. Juba Arabic as a written language. In Stefano Manfredi \& Mauro Tosco (eds.), Arabic-based pidgins and creoles, special issue of Journal of Pidgin and Creole Languages 29(2). 352-391.

Moukarbel, Nayla. 2009. Sri Lankan housemaids in Lebanon. Amsterdam: University of Amsterdam Press.

Mufwene, Salikoko S. 2000. Creolization is a social, not a structural process. In Ingrid NeumanHolzschuh \& Edgar Schneider (eds.), Degrees of restructuring in creole languages, 65-84. Amsterdam: John Benjamins.

Mufwene, Salikoko S. 2001. The ecology of language evolution. Cambridge: Cambridge University Press.

Mühlhäusler, Peter. 1997. Pidgin and creole linguistics. London: University of Westminster Press.

Næss, Unn Gyda. 2008. Gulf Pidgin Arabic: Individual strategies or a structured variety? A study of some features of the linguistic behaviour of Asian migrants in the Gulf countries. M.A. thesis, University of Oslo.

Nakao, Shuichiro. 2012. Revising the substratal/adstratal influence on Arabic creoles. In Hieda Osamu (ed.), Challenges in Nilotic linguistics and more, phonology, morphology and syntax (Studies in Nilotic linguistics 5). 127-149. Tokyo: ILCAA.

Nakao, Shuichiro. 2013. The prosody of Juba Arabic: Split prosody, morphophonology and slang. In Mena Lafkioui (ed.), African Arabic: Approaches to dialectology, 95-120. Berlin: De Gruyter.

Owens, Jonathan. 1977. Aspects of Nubi syntax. Ph.D. thesis, SOAS, University of London. 
Owens, Jonathan. 1985. The origins of East African Nubi. Anthropological Linguistics 27(3). 229-271.

Owens, Jonathan. 1990. East African Nubi: Bioprogram vs. inheritance. Diachronica 7. 217-250.

Owens, Jonathan. 1996. Arabic-based pidgins and creoles. In Sarah G. Thomason (ed.), Contact languages: A wider perspective. Amsterdam: John Benjamins.

Schuchardt, Hugo. 1882-1883. Kreolische Studien I-V. Sitzungsberichte der kaiserlichen Akademie der Wissenschaften zu Wien 101(2). 889-917; 102(2). 799-816; 103(1). 3-18; 105(1). 151-161.

Smart, Jack R. 1990. Pidginization in Gulf Arabic: A first report. Anthropological Linguistics 32. 83-118.

Thangarajah, C.Y. 2003. Veiled constructions: Conflict, migration and modernity in eastern Sri Lanka. Contributions to Indian Sociology 37. 141.

Tosco, Mauro \& Stefano Manfredi. 2013. Pidgins and creoles. In Jonathan Owens (ed.), The Oxford handbook of Arabic linguistics, 495-519. Oxford: Oxford University Press.

Van Name, Addison. 1869-1870. Contributions to creole grammar. Transactions of the American Philological Association 1. 123-167.

Versteegh, Kees. 1984. Pidginization and creolization: The case of Arabic. Amsterdam: John Benjamins.

Versteegh, Kees. 1993. Levelling in the southern Sudan: From Arabic creole to Arabic dialects. International Journal of the Sociology of Language 99. 65-97.

Versteegh, Kees. 2004. Pidginization and creolization revisited. In Martine Haak, Rudolf de Jong \& Kees Versteegh (eds.), Approaches to Arabic dialects. a collection of articles presented to Manfred Woidich on the occasion of his sixtieth birthday, 343-357. Leiden: Brill.

Wellens, Ineke. 2005. The Nubi language of Uganda: An Arabic creole in Africa. Leiden: Brill.

Wellens, Ineke. 2007. Ki-Nubi. In Kees Versteegh et al. (eds.), Encyclopedia of Arabic language and linguistics, 588-597, Volume 2. Leiden: Brill.

Whinnom, Keith. 1971. Linguistic hybridization and the special case of pidgins and creoles. In Dell Hymes (ed.), Pidginization and creolization of languages, 91-115. Cambridge: Cambridge University Press.

Winford, Donald. 2006. Reduced syntax in prototypical pidgins. In Ljilana Progovac, Kate Paesani, Eugenia Casielles \& Ellen Barton (eds.), Syntax of nonsententials: Multidisciplinary perspectives, 283-307. Amsterdam: John Benjamins.

Wiswall, Abdul-Qadir. 2002. Gulf Pidgin: An expanded analysis. Unpublished pro-seminar paper, June 3. Ohio State University.

Zapata-Barrero, Ricardo, Rocio Faúndez Garcia \& Elena Sánchez-Montijano. 2012. Circular temporary labour migration: Reassessing established public policies. International Journal of Population Research. 2012. 13 pages. Article ID 498158.

\section{Online sources}

Net. 2011. Poem in Pidgin Arabic by Kumar. http://linguisticsoman.blogspot.com/2011/12/blog-post. html

Net. 2015a. www.alnabkvb.net/vb/archive/index.php/t-38859.html

Net. 2015b.Poemin PidginArabic.https://ar-ar.facebook.com/7kayat.sudania/posts/10151404863773992.

Net. 2015c. Khalli Walli Show. www.youtube.com/playlist?list=PLM1SzQ2AvwxOPQ3mEHD6nbjGd fcD2rVht 
